In case the flower has not been visited by a Megachile the Halictus goes to the moutk of the corolla and enters in the usual way; but it usually

alights on the base first and hunts for the artificial opening.
Mt. Carmel, Ill.

J. SCHENCK.

\title{
An acknowledgment.
}

In the correcting of the proof of the paper on the ostrich fern, no. ticed in the GAZETTE for December, a paragraph stating under what conditions the investigations were made was inadvertently omitted. The Work was done under the supervision of Professor V. M. Spalding, of the University of Michigan, to whom the author begs to offer this somewhat tardy expression of his thanks for the valuable assistance and encourage-

ment received from him during the pursuance of the work.
Berlin, Germany.
Douglas H. CA

Douglas H. Campbell.

\section{CURRENT LITERATURE.}

\section{Flowers and fruit of Sparganium and Typha.}

In this monograph Dr. Dietz has given the results of a comparative study of the development of the floral and fruit structures of Sparganium and Typha. It is a good model of those studies which are necessary before botanists can speak with any definiteness upon the relationships of plants; studies which should be greatly multiplied, and which furnish a vast and useful field of labor for our ever increasing army of botanists. Taking a group of doubtful relationships, the author has laid the foundation for a rational discussion of the subject, which he promises at some subsequent time. The vegetative structures are mostly alike, but the reproductive organs show notable differences. A radical difference occurs in the positions of the flowers themselves, those of Sparganium occurring upon secondary and tertiary axes, while those of Typha are upon primary and secondary axes. Every detail in the development of the floral parts is described and figured with that minuteness that seems to leave none of the anatomical details unrecorded. The greatest differences are found in the structures of the pistil, the most apparent of which is its bicarpellary character in Sparganium, and monocarpellary character in Typha. The formation of the integuments of the seed also differs widely. In conclusion, the author considers that, while there are enough characters in common to justify retaining these two genera in one order for the present, the differences are sufficient to indicate that there may be ordinal characters. This structural study shows that Sparganium is nearest to the Pandaneæ, while Typha shows relationships to the Aroideæ.

1. Dietz, Dr. Sa NDor.-Ueber die Entwiekelung der Blüthe und Frucht von Sparganium
Tourn. und Typha Tourn. (Bibliotheca botanica, heft 5.) 60 pp., 3 plates. 4 to. Cas-
sel: Theodor Fischer, 1887, -8 marks. 


\section{$2 \mathrm{BHL}$ Biodiversity Heritage Library}

1888. "An Acknowledgment." Botanical gazette 13(2), 40-40.

https://doi.org/10.1086/326232.

View This Item Online: $\underline{\text { https://www.biodiversitylibrary.org/item/90343 }}$

DOI: https://doi.org/10.1086/326232

Permalink: https://www.biodiversitylibrary.org/partpdf/221747

\section{Holding Institution}

Missouri Botanical Garden, Peter H. Raven Library

\section{Sponsored by}

Missouri Botanical Garden

\section{Copyright \& Reuse}

Copyright Status: Public domain. The BHL considers that this work is no longer under copyright protection.

This document was created from content at the Biodiversity Heritage Library, the world's largest open access digital library for biodiversity literature and archives. Visit BHL at https://www.biodiversitylibrary.org. 